\title{
Questions at Sellafield
}

\section{London}

OF all the possible locations in Britain, a government contractor has chosen the ground beneath the Sellafield nuclear facility as the best geological site to store the plant's radioactive waste. UK Nirex, the nuclear waste management firm, last week ended an eight-year search for a suitable site by picking Sellafield over an alternative location at another nuclear facility in Dounreay for a $£ 3,000$ million national nuclear waste depository.

Nirex admits that it does not know if the Sellafield site is actually the best in Britain, nor, for that matter, does it intend to find out. Officials decided early in the search processes simply to find the most attractive site that could meet international safety guidelines for such depositories. After completing two of a planned six boreholes at each site, it decided that Sellafield's geology would pass muster. Once that was established, Nirex concluded that the estimated cost savings of $£ 1,000$ million in not having to transport the waste off the Sellafield site was reason enough to select it for the depository, and to suspend the geological analysis of the other site.

Some UK geologists are bothered that economics finally won the day. "We were concerned that the decision was premature when one looks at it from a technical point of view," says Adrian Bath of the
British Geological Survey, which did some of the research on the sites for Nirex. He says it is not yet possible, on the basis of two boreholes at each site, to distinguish which of the two final sites is better from a geological point of view. "At the end of the drilling programme when you have some 10 boreholes, then you can make a distinction," he says.

Current plans call for three 800-metre deep caverns, each 250 metres long and 35 metres high, which are eventually to hold between 700,000 and 2 million cubic metres of waste.

Last week, UK environmental groups criticized the decision, and Greenpeace released a report on the known data about the proposed sites.

The report, by independent geologist Philip Richardson, concludes that Nirex's analysis of Dounreay was based on "grossly oversimplified geological interpretation", and that the Sellafield site was characterized by "totally the wrong [in this case, highly fractured] rock type." The report concludes: "there can be no confidence in an exercise which, having searched the whole UK mainland and continental shelf, identifies two nuclear sites as the best candidates for a repository." Nirex narrowed the search to two sites in 1989 after considering some 500 other UK prospects.

Christopher Anderson

\section{UK backs out of neutron lab}

London

OFFICIALS at the troubled international neutron laboratory at Grenoble, which was shut two weeks ago after cracks were discovered in part of its reactor cooling system, received another dose of bad news last week: Britain announced that it intends to cut its funding for the centre by nearly half.

The council of the UK Science and Engineering Research Council (SERC) decided earlier in July to seek to renegotiate the current UK two-year contract with the Grenoble laboratory, known as the Insitut Laue-Langevin (ILL). Rather than maintain a one-third partnership with France and Germany in the laboratory, SERC wants to reduce its commitment from $£ 11$ million to about $£ 6$ million annually by 1994 . SERC's $£ 22$ million neutron research budget, currently split evenly between ILL and the ISIS neutron facility at the UK Rutherford-Appleton Laboratory, is to be reduced to $£ 17$ million for the 1993-94 budget. But the SERC council declared its "unambiguous commitment" to ISIS and placed it offlimits at least through 1997, leaving ILL as the only place to cut.

ILL officials say that the shortfall could be made up by bringing in another partner (Italy is rumoured to be a possibility) or by asking the other two current Germany is strongly in support of the facility and is prepared to discuss various solutions for upgrading the facility, says Anne-Marie Hanson, the official in charge of ILL at the German Ministry of Research and Technology.

In the meantime, officials hope that the UK decision will not interfere with plans to repair the reactor, a process that is expected to take at least two years (see Nature 352, 178; 18 July 1991). "The [decreased] British contract wouldn't start until in 1994," says ILL director Peter Day. "We're talking about [repairs] that might be proposed in the next few months."

At the Rutherford-Appleton Laboratory, ISIS officials have requested two extra weeks of beam time in order to accommodate some of the researchers stranded by the ILL shutdown.

Christopher Anderson partners to increase their contribution.

\section{Neuroscience} leads grants

Tokyo

NEUROSCIENCE features prominently in Japan's biggest grants for individual scientists, announced last week by Japan's Ministry of Education, Science and Culture. The boost for neurological research reflects increasing government concern about Japan's ageing population and the associated occurrence of neurological disorders among older Japanese citizens.

The ministry's 'special distinguished' grants, which are worth about US\$1-2 million for 3-5 years, are meant to go to internationally recognized researchers and usually give a good indication of where Japan's best academic research is being carried out. But defects in the grant screening process occasionally lead to odd choices, and so the awards should always be interpreted with care.

This year's 12 awards include three in the field of neuroscience. Toshiharu Nagatsu at the School of Medicine of Fujita Health University gets $¥ 205$ million ( $\$ 1.5$ million) over three years to carry out molecular genetic studies on the structure, function and pathology of catecholamine neurons, which play important roles in the higher functions of the central nervous system.

Similarly, Yasuo Ihara at the Institute of Brain Research at Tokyo University, was awarded $¥ 105$ million over three years to examine modifications of a microtubule protein called tau that occurs in the fibrous structures associated with Alzheimer's disease. And Shigetada Nakanishi of Kyoto University, gets one of this year's biggest grants - $¥ 237$ million over four years - to study the function and regulation of glutamate receptors, which play a key role in memory acquisition and learning.

Japan is one of the most rapidly 'greying' nations in the developed world. A postwar baby boom followed by a plunging decline in birthrate means that the population will be dominated by elderly people early in the next century. As a result, pharmaceutical companies and the government are pouring investment into the development of cures for neurological disorders associated with old age.

Among other grants of practical interest is one to Masayoshi Esashi of Tohoku University to make microactuators using photofabrication techniques. This project, which will be funded with $¥ 232$ million over four years, forms part of a steady push by Japan to develop micromachines and nanotechnology. And Jun Akimitsu of Aoyama-Gakuin University gets $¥ 180$ million for three years to find new hightemperature oxide superconductors.

David Swinbanks 